\title{
Preliminary Study of Fluidization Curves in Polydisperse Beds Formed by a Binary Mixture of Raphanus sativus L. Husk and Sand
}

\author{
Leandro Gomes ${ }^{1 *}$, Vitória Sgorla ${ }^{1}$, Angenor Auler ${ }^{1}$, Matheus Villares ${ }^{1}$, Jonatan Vuelma ${ }^{2}$, \\ Flávia Zinani², Fernando Santos ${ }^{1}$ \\ ${ }^{1}$ Department of Engineering, Universidade Estadual do Rio Grande do Sul, Porto Alegre-RS, Brazil \\ ${ }^{2}$ Institute of Petroleum and Natural Resources, Pontifícia Universidade Católica do Rio Grande do Sul, Porto Alegre-RS, Brazil \\ Email: *fernandoasantos7@gmail.com
}

How to cite this paper: Gomes, L., Sgorla, V., Auler, A., Villares, M., Vuelma, J., Zinani, F. and Santos, F. (2017) Preliminary Study of Fluidization Curves in Polydisperse Beds Formed by a Binary Mixture of Raphanus sativus L. Husk and Sand. Open Access Library Journal, 4: e3713.

https://doi.org/10.4236/oalib.1103713

Received: June 6, 2017

Accepted: August 18, 2017

Published: August 21, 2017

Copyright $\odot 2017$ by authors and Open Access Library Inc.

This work is licensed under the Creative Commons Attribution International License (CC BY 4.0).

http://creativecommons.org/licenses/by/4.0/

\begin{abstract}
Seeking to use an increasingly clean and sustainable energy matrix, the use of biomass derivatives becomes an increasingly present alternative. Among the processes that can be used to generate higher added value products from biomass, the gasification process is highlighted. The irregular and spherical shape of the biomass particles inserted in the bed make this process difficult, however, and it is necessary to add an inert material (usually sand), forming a polydisperse bed filled with a binary mixture, but the biomass/sand is extremely important for the fluidization process to occur. Therefore, the present work had the objective of determining the fluidization curves of a binary mixture of sand and fodder turnip, which is formed by $10 \%, 30 \%, 50 \%, 70 \%$ and $90 \%$ of biomass in its volume. The fluidization of the Raphanus sativus L. husk fluidized up to a $70 \%$ biomass ratio in the blend, increasing the yield of the system and providing a viable and sustainable alternative for the application of biomass in biorefinery processes.
\end{abstract}

\section{Subject Areas}

Biochemistry

Keywords

Fluidized Bed, Gasification, Raphanus sativus L. Biomass

\section{Introduction}

The search for the substitution of fuels that can replace the energy coming from 
fossil fuels has given the sources of renewable energy a prominent role in the energetic scene. Fossil fuels, finite and highly polluting, are losing ground to the energy generated from the sun, the winds and biomass [1]. Biomass, bioenergy and bioproducts through biorefinery processes, have a significant role in biomass, especially because of its versatility and storage capacity [2].

Still according to Santos [2], biomass can be defined as any organic compound, of animal or vegetable origin, that can be converted into a bioproduct. Among the biomasses that present great potential for use in biorefinery processes, it is worth mentioning the Raphanus sativus $L$. This legume has a short-lived phenological cycle, which makes it feasible for green manuring in the off-season [3]. Faria [3] still complements that residues from the production of Raphanus sativus L. are commonly used in the manufacture of animal feed. The concept of biorefinery, however, can provide a nobler destination for this waste, generating income for producers and helping to form a cleaner energy matrix.

The use of the chemical and energy potential of biomass can be done through chemical, biochemical or thermochemical routes. Within the thermochemical routes, the conversion of the biomass into bioelectricity becomes extremely efficient through the combustion of it in fluidized bed reactors. Fluidization allows a greater homogenization of temperature in the reactor by increasing the contact surface between the upward fluid in the bed and the fuel to be fluidized, generating high rates of heat transfer and mass [4].

One of the obstacles to the use of biomass in fluidization processes, according to Genher [5], is its irregular nature, with random formats, which make its fluidization difficult, so, for the fluidization of the biomass, it is necessary to add an inert material with greater sphericity. It would facilitate a fluidity of a large amount of biomass. The most commonly used are sand, calcite or alumina.

The fluidization process of this binary mixture is influenced, among other things, by the proportion of biomass, considering that a mixture containing large amounts of biomass tends to present greater fluidization difficulties, forming preferential paths in the bed or causing segregation of the parts of the mixture [5]. In this way, the goal of the present work was to study the influence of the increase of biomass in a binary mixture of biomass and sand.

Through this study, it is possible to verify the possibility of using Raphanus sativus $L$. in gasification processes as well as to optimize the feed rate of the fluidized bed reactor.

Fluidization is a necessary instrument for gasification of biomass, a process by which a solid fuel is transformed into a gaseous fuel, which can be commercialized for the generation of bioproducts or as a source of heat, thus offering a new alternative to the energy matrix.

\section{Materials and Methods}

\section{Raphanus sativus L.}

A legume belonging to the Brassicaceae family, Raphanus sativus $L$. is an oilseed 
commonly used in green manuring and crop rotation in the central-west, south and southeast regions of Brazil [6]. It presents a high content of protein and oil, which can reach up to $40 \%$, being used in the manufacture of animal feed [7].

The Raphanus sativus L. can be visualized in Figure 1. It can reach 1 meter in height, it has an annual cycle, being a plant with several branches [8]. Being a fast-growing plant, it is able to cover up to $70 \%$ of the soil surface after 60 days of germination. Its phenological cycle varies between 150 and 180 days [9] [10].

The biomass used in the experiment was provided by the State University of Rio Grande do Sul, located in Três Passos, which originates from the experimental cultivation area of the Agronomy course. As standout characteristics, the cultivar presents a high capacity of cycling of nutrients such as nitrogen and phosphorus, and then, the capacity to develop in soils considered poor for other crops [11].

The Raphanus sativus L. husk was cultivated and supplied by the Universidade Estadual do Rio Grande do Sul in Três Passos/RS unit. The Raphanus sativus $L$. was placed in a stove to remove moisture at a temperature of $105^{\circ} \mathrm{C}$ for a period of 8 hours in constant homogenization.

After this step, was used, in the Laboratory of Characterization and Valorization of Materials (LCVMAT), of the Universidade do Vale do Rio dos Sinos, the knife mill of brand SEIBT, type MGHS $270 \mathrm{~A}$, With a $4 \mathrm{~mm}$ sieve, allowing the biomass to be reduced in size (Figure 2).

After the milling process, the specific mass of the biomass as well as the sand, used as an inert material during the fluidization, was determined.

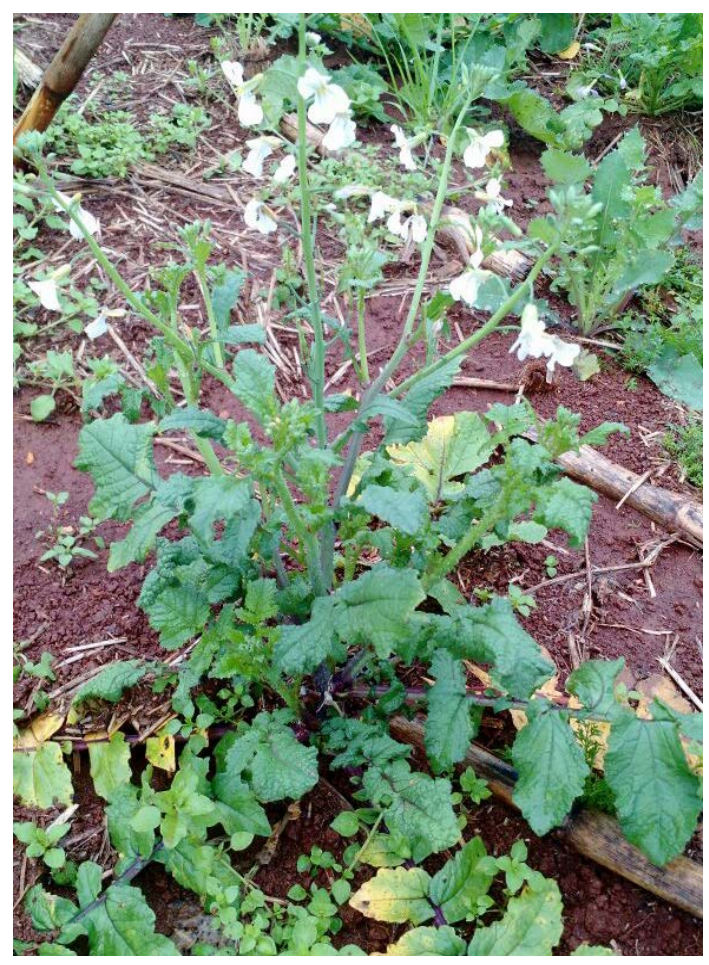

Figure 1. Raphanus sativus L. 


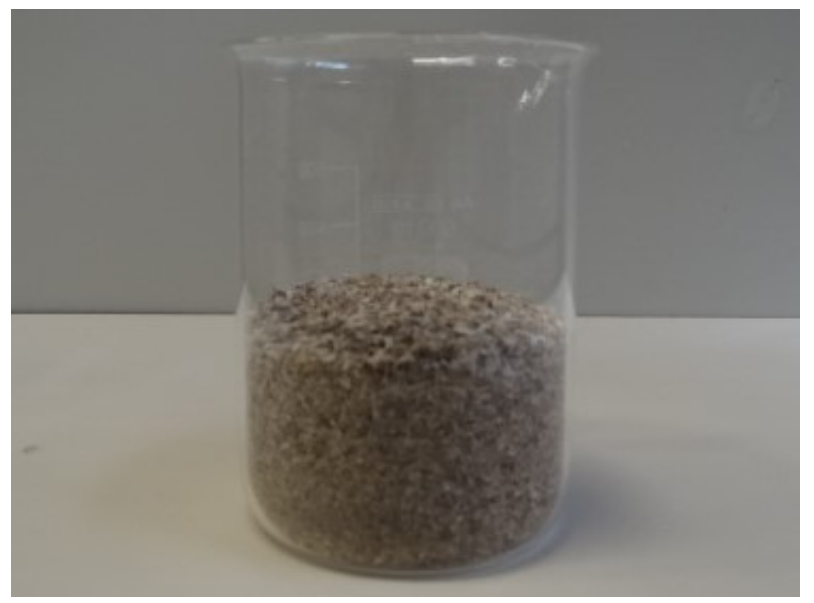

Figure 2. Raphanus sativus L. husk after milling process.

In the determination of the specific mass, according to norm NP EM 1097-6, the pycnometry with water was performed. By this analysis, it was possible to obtain the actual specific mass of the sand used in the binary mixture; however, due to the low density of the biomass particles, it was not possible to obtain its actual specific mass values through this test.

Due to the impossibility of determining the actual specific mass of the biomass via pycnometer with water, the analysis was changed for helium gas pycnometer. The pycnometer used was Micromeritics, model AccuPcy II 13 of the LCVMAT.

To measure the apparent density of the material, the mass of material needed to fill the bed up to the height $(\mathrm{H})$ of $94 \mathrm{~mm}$ was measured, this value being also corresponding to the bed diameter $(D)$. In this way, the ratio $H / D \approx 1$. For the preparation of the samples was defined as standard volume $2.60 \times 10^{-3} \mathrm{~m}^{3}$, this being the standard volume used in the preparation of the samples. The ratio obtained between the mass of the material and its apparent volume determined the apparent specific mass of the material.

With the apparent density of the biomass and the apparent density of the sand, the biomass and sand mixtures were made in different volumetric proportions, containing $10 \%, 30 \%, 50 \%, 70 \%$ and $90 \%$ of biomass, being complemented by the addition of inert material. The mixtures were sent to the fluidization bed (Figure 3), where the experiment was performed.

The fluidization bed consists of a cylindrical acrylic tube that has an internal diameter of $94 \mathrm{~mm}$ and a wall thickness of $3 \mathrm{~mm}$. At the bottom of the bed, there is a $100 \mathrm{~mm}$ stainless steel tube. This is called a distributor, whose purpose is to distribute the upward flow of fluid uniformly throughout the cross-sectional area of the bed. Below the distributor is a semiconductor in which the fluid used is inflated in the bed. The fluid used in the experiment was air.

At the ends of the distributor, there are metallic screens; the one located at the lower end serves to support the glass beads, randomly arranged in the dispenser, while the screen at the top of the dispenser serves to support the material to be fluidized, which comes to compose the bed. 


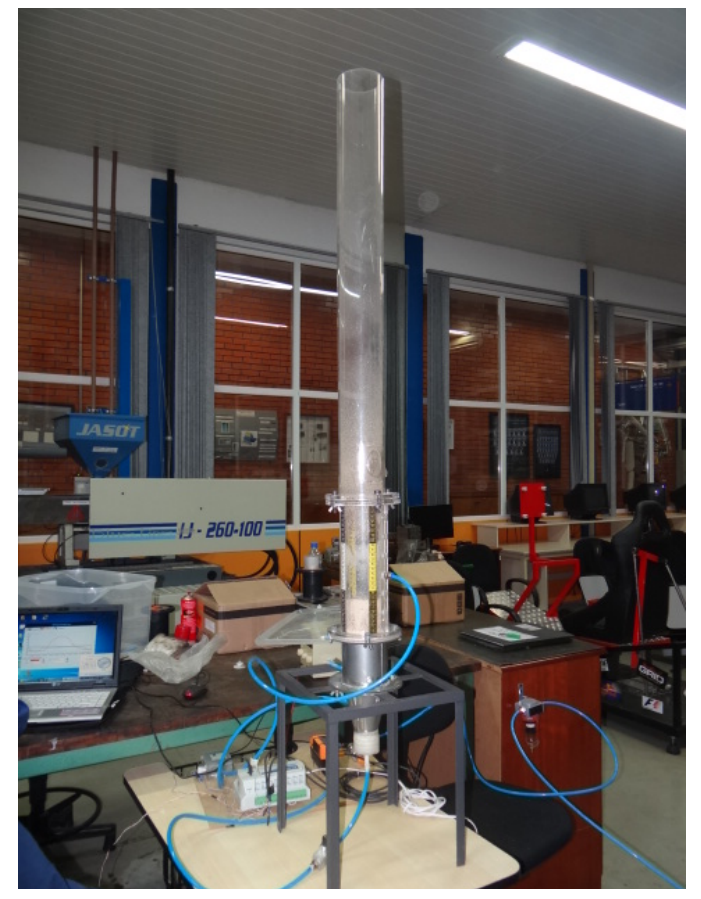

Figure 3. Fluidization bed.

Figure 4 shows the composition of the fluidization bed with all of the components mentioned above.

For the measurement of the flow of the compressed air inflated in the bed a meter, which brand is IFM, type SD6050, which measures pressure in the range of 0.2 to $75 \mathrm{Nm}^{3} / \mathrm{h}$, with an accuracy of $\pm 1.5 \%$ and analogue signal output in the range of 4 to $20 \mathrm{~mA}$.

The pressure difference was used to determine the load loss occurring during the passage of fluid through the bed. For this, pressure is drawn from the fluid inflated in the bed, before passing through the distributor, and the fluid after passing through the column of fluidized material. This second pressure take-off occurs through an orifice located above the column of the material composing the bed.

For this pressure take-off was used the equipment, which brand is NOVUS, type HUBA 699, With adjustable measuring range between 0 to 16 mbar, 0 to 25 mbar e 0 to 50 mbar, as well as a data collection board, type Fieldlogger. The data were collected simultaneously at each second in real time through software, allowing analysis of the behavior of the pressure loss according to the increase of fluid flow in the bed.

After the mixture of biomass and sand was inserted in the bed, the air flow was increased to homogenize. After the airflow was interrupted, the bed was put back in its initial position for the experiment to be performed. The air flow was increased manually, during the increase of the air flow, the expansion of the bed, and after reaching a limit, it was noticed the appearance of air bubbles on the surface of the bed. 


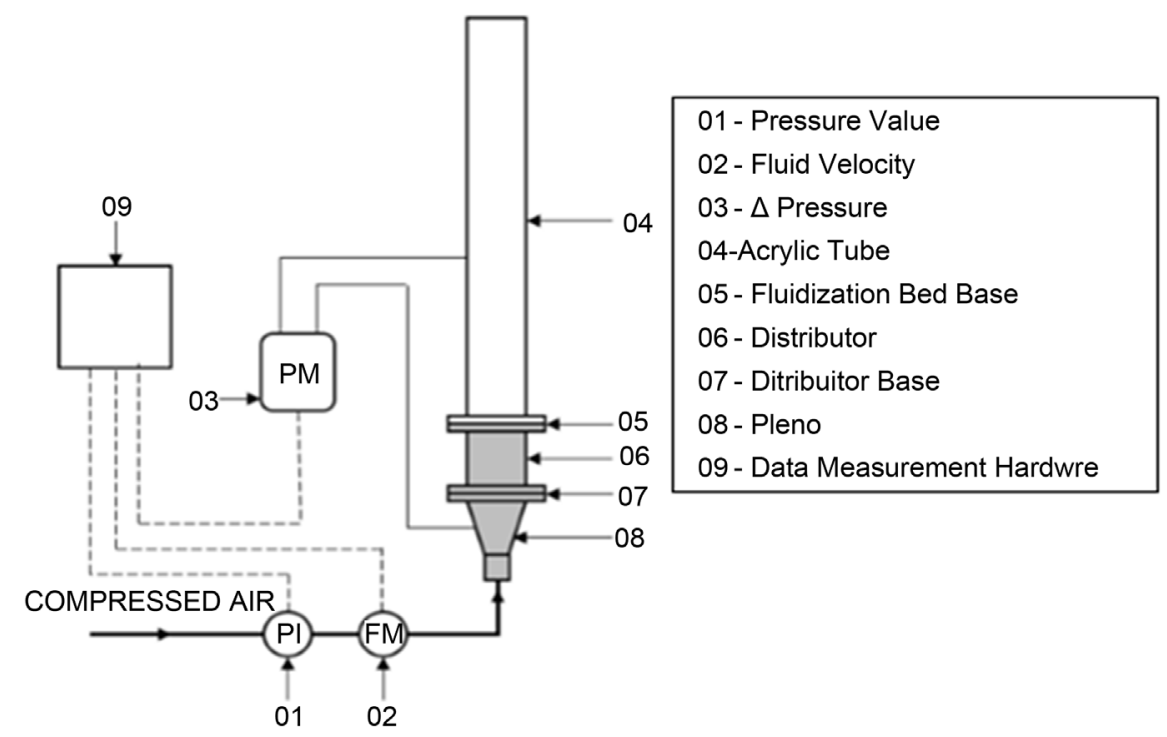

Figure 4. Fluidization bed [5].

\section{Results and Discussion}

The actual and apparent densities of the sand and forage turnip obtained can be seen in Table 1 . The results for the Raphanus sativus L. husk were compared with those obtained by Genehr [5] that made the fluidization of eucalyptus and pinus chips also using sand as an inert material.

It was noted that both the specific mass and apparent density of the Raphanus sativus L. are lower than that of Pinus and Eucalyptus. The apparent density interferes with the mass of the biomass present in the mixture, which in turn will impact on the fluidization process of mixtures with a large amount of biomass, mainly in the formation of preferred paths in the segregation of the mixture. The volumetric proportions of biomass in the mixture were chosen to cover two extreme scenarios, the first one in which the amount of biomass is small, being only $10 \%$, and the second in which the amount of biomass is the majority, being $90 \%$. Thus, a standard volume of was established, and using the apparent density of the biomass and the sand, the masses were calculated so that the mixtures with the established proportions were obtained.

The mass fractions ( $\chi_{\text {Raphanus Sativus L. }}$ ) present in each fluidized mixture can be seen in Table 2.

After the fluidizations were carried out, the load loss curves ( $\Delta$ pmbar) as a function of the upflow fluid flow rate $\left(\mathrm{Nm}^{3} / \mathrm{h}\right)$ were obtained by collecting the data in real time. After the conversion of the flow unit, the curve describing the load loss as a function of the inflow velocity of the upward fluid in the bed was obtained. To facilitate the presentation of results a curve identification code was established:

\section{CNF-XX.Y}

Where XX corresponds to the volumetric percentage of biomass in the mixture, 
Table 1. Specific mass of bed components.

\begin{tabular}{ccc}
\hline Density & {$\left[\mathrm{g} / \mathrm{cm}^{3}\right]$} & Reference \\
\hline$\rho_{\text {Raphanus Sativus } L \text { Husk }}$ & 0.723 & Author \\
$\rho_{\text {sand }}$ & 2.61 & Author \\
$\rho_{\text {ap. Raphanus Sativus } L}$ & 0.116 & Author \\
$\rho_{\text {ap.sand }}$ & 1.554 & Author \\
$\rho_{\text {eucalyptus }}$ & 1.386 & Genehr \\
$\rho_{\text {pinus }}$ & 1.271 & Genehr \\
$\rho_{\text {ap.eucalyptus }}$ & 0.93 & Genehr \\
$\rho_{\text {ap.pinus }}$ & 0.77 & Genehr \\
\hline
\end{tabular}

Table 2. Mass fractions of the mixtures.

\begin{tabular}{cccc}
\hline \multirow{2}{*}{$\%$ Volumetric of biomass } & \multicolumn{3}{c}{ Mass } \\
\cline { 2 - 4 } & sand $(\mathrm{g})$ & $\begin{array}{c}\text { Raphanus sativus L. husk } \\
(\mathrm{g})\end{array}$ & $\chi_{\text {Raphanus Sativus L. }}$ \\
\hline $10 \%$ & 912.36 & 7.54 & $1 \%$ \\
$30 \%$ & 709.61 & 22.62 & $3 \%$ \\
$50 \%$ & 506.87 & 37.71 & $7 \%$ \\
$70 \%$ & 304.12 & 52.79 & $15 \%$ \\
$90 \%$ & 101.37 & 67.87 & $40 \%$ \\
\hline
\end{tabular}

assuming the values of $10,30,50,70$ or 90 , and $Y$ will assume the letter $F$, indicating the fluidization process, or the letter $\mathrm{D}$, indicating the process of defluidization.

The fluidization and defluidization curves are shown in the graphs of Figure 5 below, highlighting the apparent fluid velocity points (Ufa) obtained after analysis of the fluidization curves and the minimum fluidization velocity (Umf) obtained after analysis of the curves of defluidization.

It is possible to observe, after the data analysis, that the increase of the ratio of Raphanus sativus L. husk causes the decrease in the load loss, in contrast, increasing both the apparent fluidization velocity and the minimum fluidization velocity (Table 3 ).

The $\mathrm{U}_{\mathrm{fa}}$ is determined experimentally by the point of greatest loss of charge during the fluidization process. Upon reaching the velocity corresponding to the maximum loss of charge the particles of the bed start to move and the bed then passes from the fixed to the fluidized state.

During the defluidization process, the $\mathrm{U}_{\mathrm{mf}}$ occurs at the intersection between the line at which the pressure is stabilized, and the fluidization curve of the immersing component of the blend.

The reduction of the load loss in the mixtures with greater amount of biomass can be understood by the decrease in the total mass of the mixture, due to the lower density of the biomass compared to the sand used, thus the drag force ne- 
CNF-10.F

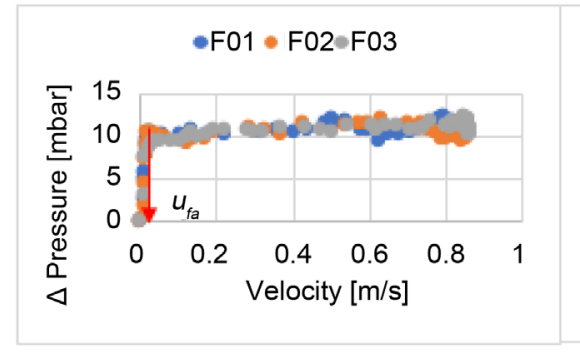

CNF-30.F

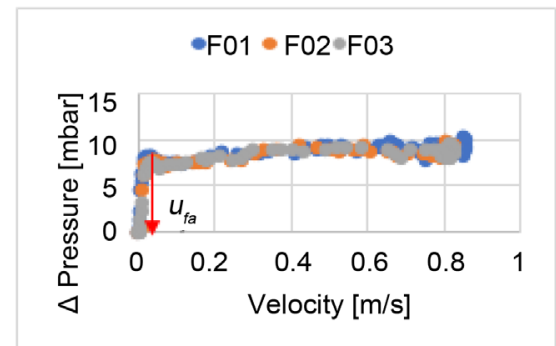

CNF-50.F

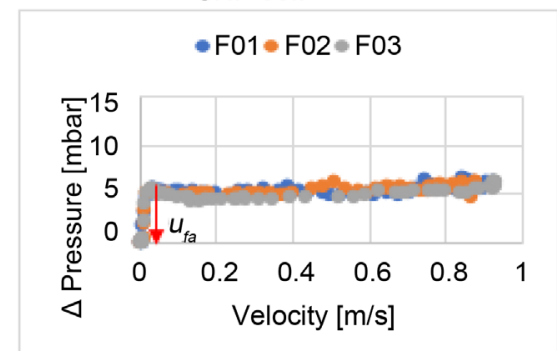

CNF-70.F

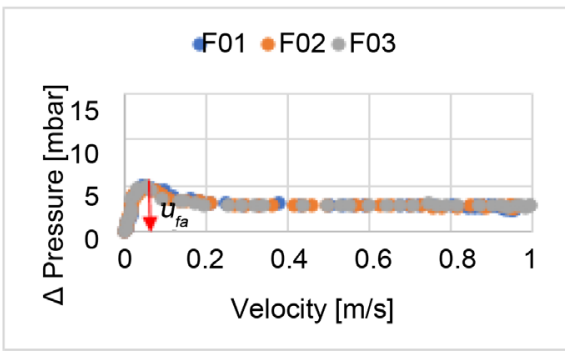

CNF-90.F

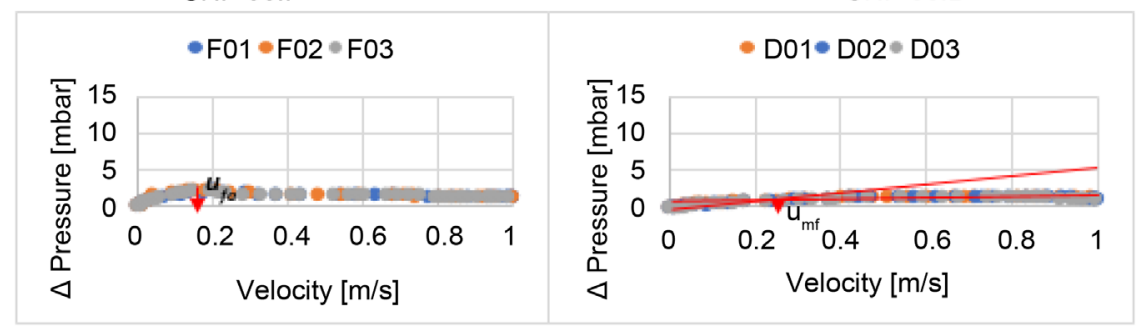

CNF-10.D

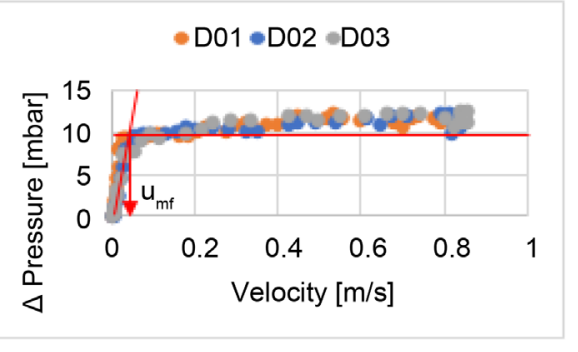

CNF-30.D

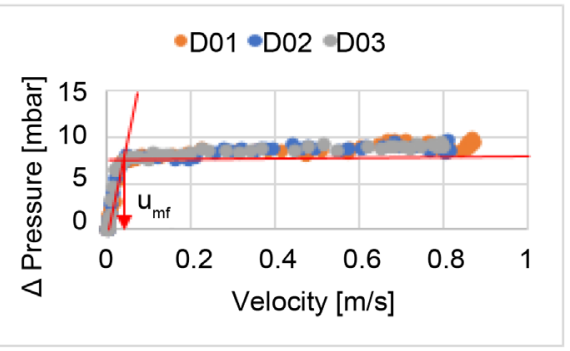

CNF-50.D

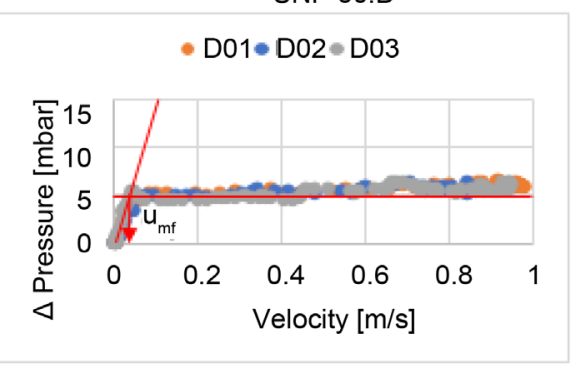

CNF-70.D

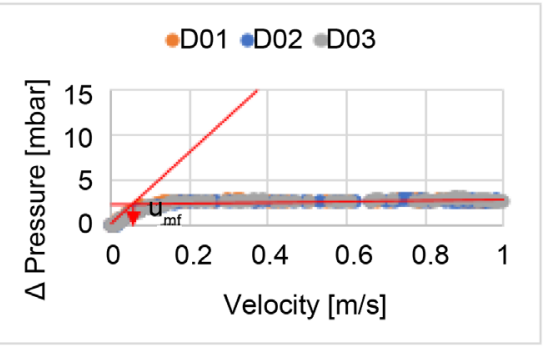

CNF-90.D

Figure 5. Fluidization and defluidization curves.

cessary to compensate the weight force of the particles becomes smaller, which causes the air load loss to be smaller. On the other hand, the higher biomass increase in the mixture favors the appearance of preferential paths, which, in addi- 
tion to contributing to the reduction of the load loss, causes an increase in both the apparent fluidization velocity and the minimum fluidization velocity (Figure 6). So that the preferred paths are undone, it is necessary to increase the air flow.

The increase in airflow, however, causes the entrainment of the bed particles, causing a large amount of biomass to be lost. The irregular and low sphericity form of the biomass also contributes to the segregation processes of the bed mix occurring.

In the process of fluidization containing Pinus and Eucalyptus, Genehr [5] observed the formation of preferential paths, which caused an abrupt drop in the fluid load loss already in the mixture containing 50\% biomass and 50\% sand. This state makes the fluidization process impossible, so that a very large velocity of the upward fluid is required for the preferred paths to be undone. In this state of fluidization, however, the transport of part of the biomass out of the bed occurs, causing the system to lose efficiency. During the fluidization of the Raphanus sativus $L$. the mixture containing $70 \%$ of biomass presents a low formation of preferred paths, which contributes to the fluidization process occurring with a higher proportion of biomass, provoking an increase in the fluidization efficiency.

\section{Conclusions}

Increasing the proportion of Raphanus sativus $L$. in the bed of a fluidized bed

Table 3. Fluidization rates.

\begin{tabular}{ccccc}
\hline$\square_{\text {Raphanus Sativus } L \text { husk }}$ & $\mathrm{U}_{\mathrm{fa}}[\mathrm{m} / \mathrm{s}]$ & $\Delta_{\text {pressure }}[\mathrm{mbar}]$ & $\mathrm{U}_{\mathrm{mf}}[\mathrm{m} / \mathrm{s}]$ & $\Delta_{\text {pressure }}[\mathrm{mbar}]$ \\
\hline $1 \%$ & 0.0262 & 10.597 & 0.0280 & 9.444 \\
$3 \%$ & 0.0319 & 8.197 & 0.0279 & 7.528 \\
$7 \%$ & 0.0303 & 5.513 & 0.0386 & 5.529 \\
$15 \%$ & 0.0454 & 4.980 & 0.0723 & 2.603 \\
$40 \%$ & 0.1469 & 2.021 & 0.1740 & 1.436 \\
\hline
\end{tabular}

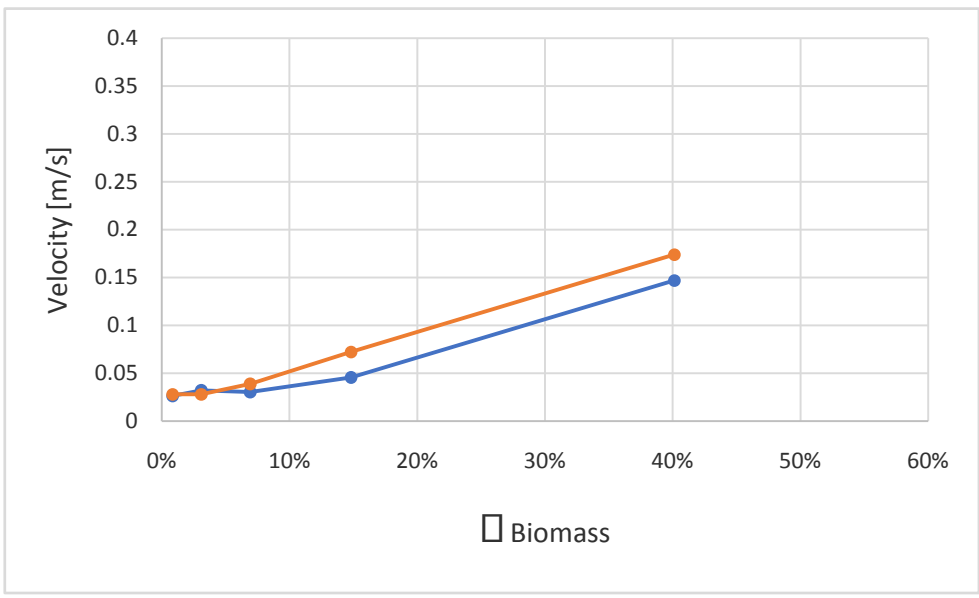

Figure 6. Velocity $\mathrm{x} \square_{\text {biomass }}$ 
reactor causes the formation of small-preferred paths, which provide for the decrease of bed load loss.

The increase of the flow of the fluid causes the biomass particles to be dragged out of the bed, causing the loss of biomass, consequently reducing the efficiency of the system. This fact is mainly due to the large difference in the specific mass of the sand particles and the Raphanus sativus L., as well as the low spherical shape of the biomass particles, which favors their drag.

Finally, for the use of the Raphanus sativus L. presented in fluidized bed reactors, it is necessary to control the proportion of biomass and inert material, and in the experiment, the mixture containing the proportion of 50\% sand and 50\% of Raphanus sativus $L$. has not caused a significant change in the fluid pressure drop, which indicates the absence of preferred paths, thus providing an interesting proportion for use on a larger scale.

\section{References}

[1] Eichler, P., Santos, F., Toledo, M., Zerbin, P., Schmitz, G., Alves, C., Ries, L. and Gomes, F. (2015) Produção do biometanol via gaseificação de biomassa lignocelulósica. Química Nova, 38, 828-835.

[2] Santos, F., Colodette, J. and Queiroz, J.H. (2013) Bioenergia e Biorrefinaria: Cana-de-Açúcar e Espécies Florestais. Viçosa.

[3] Faria, D.J. (2016) Extração do óleo de sementes de nabo forrageiro (raphanus sativus L.) e avaliação do seu potencial na produção de biodiesel. Bachalor Thesis, Universidade Estadual do Rio Grande do Sul, Novo Hamburgo.

[4] Warnecke, R. (2000) Gasification of Biomass: Comparison of Fixed Bed and Fluidized Bed Gasifier. Biomass and Bioenergy, 18, 489-497.

http://www.sciencedirect.com/science/article/pii/S096195340000009X

[5] Genehr, G.A. (2015) Caracterização da fluidização de biomassas de casca de madeiras em leitos polidispersos. Master Thesis, Universidade do Vale do Rio dos Sinos, São Leopoldo.

[6] Crusicol, C.A.C., Coticca, R.L., Lima, E.V., Andreotti, M., Moro, E. and Marcon, E. (2005) Persistência de palhada e liberação de nutrientes do nabo-forrageiro no plantio direto. Pesquisa Agropecuária Brasileira, 40, 161-168.

http://www.scielo.br/scielo.php?script=sci_arttext\&pid=S0100-204X2005000200009 https://doi.org/10.1590/S0100-204X2005000200009

[7] Abdalla, A.L., Filho, J.C.S., Godoi, A.R., Carmo, C.A. and Eduardo, J.L.P. (2008) Utilização de subprodutos da indústria de biodiesel na alimentação de ruminantes.

Revista Brasileira de Zootecnia, 37, 260-258. https://doi.org/10.1590/S1516-35982008001300030

[8] Lorenzi, H. (2006) Manual de identificação e controle de plantas daninhas. 6th Edition, Plantarum, São Paulo.

[9] Theisen, G. (2008) Aspectos botânicos e relato da resistência de nabo silvestre aos herbicidas inibidores de ALS. Embrapa, São Paulo.

[10] Calegari, A. (1998) Plantio direto: Pequena propriedade sustentável. Iapar, Londrina.

[11] Sluszz, T. and Machado, J.A.D. (2006) Características das potenciais culturas matérias-primas do biodiesel e sua adoção pela agricultura familiar. XLIV Congresso da Sober, Fortaleza, 23-25 July 2006, 20. 
Submit or recommend next manuscript to OALib Journal and we will provide best service for you:

- Publication frequency: Monthly

- 9 subject areas of science, technology and medicine

- Fair and rigorous peer-review system

- Fast publication process

- Article promotion in various social networking sites (LinkedIn, Facebook, Twitter, etc.)

- Maximum dissemination of your research work

Submit Your Paper Online: Click Here to Submit

Or Contact service@oalib.com 